Support statement: P. Trip and A. Vonk-Noordegraaf were supported by the Netherlands Organization for Scientific Research (NWO)-VIDI (project number 917.96.306).

Conflict of interest: Disclosures can be found alongside the online version of this article at www.erj.ersjournals.com

\title{
References
}

1 Deng Z, Morse JH, Slager SL, et al. Familial primary pulmonary hypertension (gene PPH1) is caused by mutations in the bone morphogenetic protein receptor-II gene. Am J Hum Genet 2000; 67: 737-744.

2 The International PPH Consortium, Lane KB, Machado RD, et al. Heterozygous germline mutations in BMPR2, encoding a TGF- $\beta$ receptor, cause familial primary pulmonary hypertension. Nat Genet 2000; 26: 81-84.

3 Sztrymf B, Coulet F, Girerd B, et al. Clinical outcomes of pulmonary arterial hypertension in carriers of BMPR2 mutation. Am J Respir Crit Care Med 2008; 177: 1377-1383.

4 Trip P, Nossent EJ, de Man FS, et al. Severely reduced diffusion capacity in idiopathic pulmonary arterial hypertension: patient characteristics and treatment responses. Eur Respir J 2013; 42: 1575-1585.

5 Macintyre N, Crapo RO, Viegi G, et al. Standardisation of the single-breath determination of carbon monoxide uptake in the lung. Eur Respir J 2005; 26: 720-735.

6 Stacher E, Graham BB, Hunt JM, et al. Modern age pathology of pulmonary arterial hypertension. Am J Respir Crit Care Med 2012; 186: 261-272.

7 Galiè N, Hoeper MM, Humbert M, et al. Guidelines for the diagnosis and treatment of pulmonary hypertension. Eur Respir J 2009; 34: 1219-1263.

Montani D, Price LC, Dorfmuller P, et al. Pulmonary veno-occlusive disease. Eur Respir J 2009; 33: 189-200. Quanjer PH, Tammeling GJ, Cotes JE, et al. Lung volumes and forced ventilatory flows. Eur Respir J 1993; 6: Suppl. $16,5-40$.

10 Guazzi M. Alveolar gas diffusion abnormalities in heart failure. J Card Fail 2008; 14: 695-702.

Eur Respir J 2014; 43: 1195-1198 | DOI: 10.1183/09031936.00136413 | Copyright @ERS 2014

\section{Verrucous carcinoma of the tracheobronchial tree: an underdiagnosed entity?}

\section{To the Editor:}

Verrucous carcinomas, first described by ACKERMANN [1] in 1948, are rare, well-differentiated squamous cell carcinomas in the oropharynx [2], larynx [2-4] and oesophagus [5], and seem to be associated with Human papilloma virus (HPV) infections [6]. Macroscopically, they have a warty appearance and may easily be mistaken for papillomas [4]. Surprisingly, although found in the larynx, there are no descriptions of this tumour in the tracheobronchial tree.

A 74-year-old male with a history of chronic obstructive pulmonary disease and former smoking was admitted for increasing shortness of breath. On clinical investigation he had a subfebrile temperature $\left(38.2^{\circ} \mathrm{C}\right)$ and dry rales. Chest radiography showed discrete infiltrates in the right lower lobe. Lung function testing revealed an obstructive flow-volume loop with a forced expiratory volume in $1 \mathrm{~s}$ (FEV1)/forced vital capacity ratio of $32 \%$ and a FEV1 of $1.1 \mathrm{~L}$ (37\% predicted).

Although anti-obstructive treatment was intensified using inhaled $\beta$-adrenergics, steroids and antibiotic treatment (ampicillin/sulbactam), the dyspnoea did not improve. On bronchoscopy, the distal trachea was shown to be infiltrated by a wart-like tumour obstructing $\sim 70 \%$ of the cross sectional area (fig. 1 ). The tumour was partly removed during rigid bronchoscopy and partly destroyed by Nd:YAG (neodymiumdoped yttrium aluminum garnet) laser and cryotherapy.

As the features of the tumour raised the suspicion of squamous cell carcinoma, the patient was referred to the department of radiation oncology for radiation therapy. Histological examination of the tumour specimens revealed a papillary hyperplastic squamous epithelium without cell abnormalities. Ki-67 and p63 immunostaining showed a slightly increased proliferation rate in the middle layer of the epithelium. In situ hybridisation for the detection of HPV serotypes 1, 6, 7, 16, 18 and 31 showed evidence of previous HPV infection.

DNA image cytometry was performed in order to distinguish between hyperplastic and neoplastic lesions. Feulgen staining identified DNA contents in multiples of two in the euploid cells. In addition, stem lines at odd multiples $(2.5 \mathrm{c}$ and $5 \mathrm{c})$ could be found. 
FIGURE 1 Macroscopic view at first bronchoscopy.

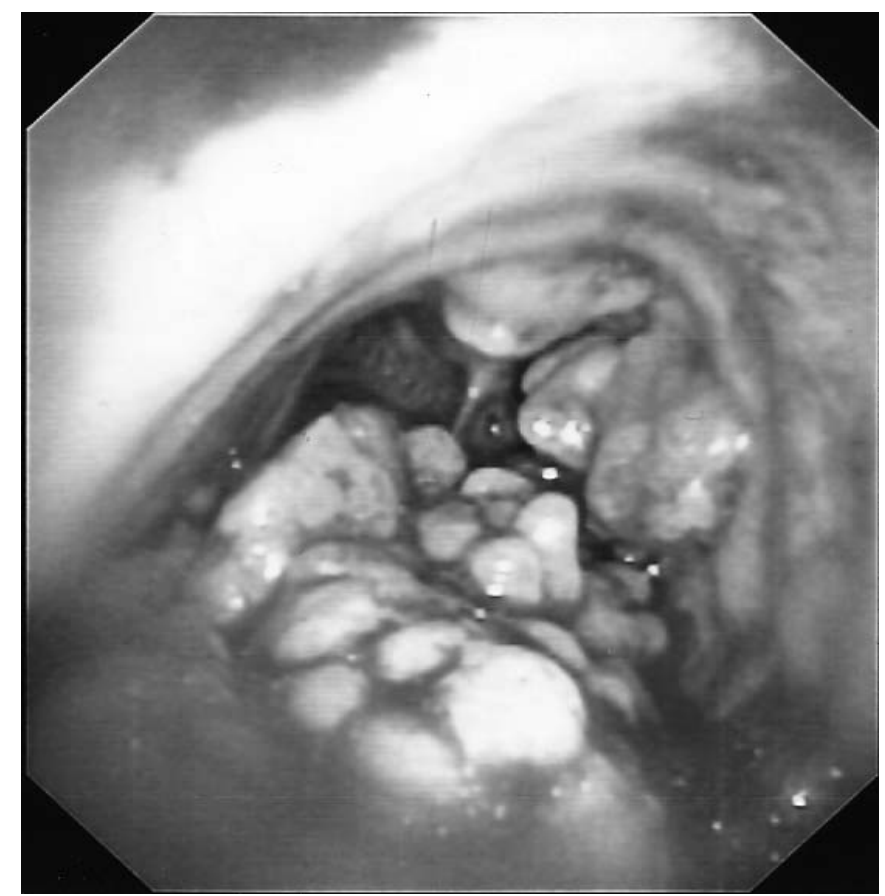

Knowing the HPV-RNA content of the tumour, it was decided not to perform radiation therapy. Further staging including 18-FDG $\left(2-\left({ }^{18} \mathrm{~F}\right)\right.$ fluoro-2-deoxy-D-glucose) positron emission tomography-computed tomography $(\mathrm{CT})$, thoraco-abdominal and brain $\mathrm{CT}$ as well as a radionuclide bone scan did not provide evidence of regional or distant metastases. Therefore, the remaining suspicious looking tissue was destroyed by cryotherapy in a third bronchoscopic procedure.

Spirometry after removal of the entire tumour was completely normal. Follow-up using chest CT and bronchoscopy was performed 1, 2, 3, 6, 12 and 18 months after the procedure. After both 4 and 8 weeks, irregularities were found in the tracheal mucosa, they were biopsied and classified as granulation tissue. To date, 24 months after the initial diagnosis, the patient has been recurrence-free.

Verrucous carcinomas are rare, well-differentiated squamous cell carcinomas that in most cases seem to be confined to the basal membrane, but invasive growth and loco-regional metastases have also been described [7]. While there are a number of reports on verrucous carcinomas of the larynx, we could not find any reports about verrucous carcinomas in the tracheobronchial tree. There is only one case report about a squamous cell carcinoma in a solitary papilloma [8]. While the clinical appearance of this tumour resembles that of our case, the authors of the report decided on a surgical resection of the involved part of the trachea.

As verrucous carcinomas mostly only show low-grade dysplasia and focal invasion with an otherwise benign appearance, diagnosis based on biopsies is difficult or even impossible [5, 9]. Therefore, most definitive diagnoses are based on the examination of resected specimens [5, 10]. Devlin et al. [5] described a verrucous carcinoma of the oesophagus with features very similar to the tumour found in our case. The authors performed multiple biopsies of the tumour, none of which showed signs of malignancy. After resection there was only one focus of submucosal infiltration with high-grade dysplasia that showed this tumour to be malignant.

In our case we could not find mitoses or infiltration as signs of malignancy. As verrucous carcinomas are often related to HPV infections, in particular to serotypes 16, 18, 31, 33, 39, 45, 52, and 58 [11], we used in situ hybridisation to prove HPV infection. Chromosomal aneuploidy is an early event in malignant transformation, especially in HPV- associated tumours [10]. To differentiate between a benign papilloma and a carcinoma, we used DNA image cytometry which showed aneuploid stem lines at $2.5 \mathrm{c}$ and $5 \mathrm{c}$ proving the malignant nature of the tumour.

The therapy of choice for verrucous carcinomas of the oropharynx and larynx is surgical resection or, at least, complete excision in the early stages. Adjuvant radiotherapy has been reported for the treatment of advanced stages of the tumour $[5,12]$. As we did not perform tracheal resection, but partly removed the tumour during rigid bronchoscopy and partly destroyed it using Nd:YAG laser and cryotherapy, we referred the patient for adjuvant radiotherapy. However, based on older publications stating that radiotherapy of 
verrucous carcinoma may lead to dedifferentiation and a higher risk of recurrence, adjuvant radiotherapy was refused by our radiation oncologists [13]. Therefore, we removed the remaining suspicious looking areas of the tracheal mucosa by cryoablation.

While spirometries performed in the years before the diagnosis had shown a gradual worsening of the obstructive shape of the flow-volume curve, spirometry performed after removal of the tumour proved complete normalisation. We suppose that the earlier findings were caused by a slow growth of the tumour and that malignant transformation may have happened shortly before our diagnosis.

Since most verrucous carcinomas are slowly growing tumours, we suggest that the first treatment of choice should be local thermal ablation with tracheal resection being a treatment option for recurrent disease. After local intervention a close follow-up with bronchoscopy and CT scan is mandatory in order to detect potential recurrence and guide further therapy.

When diagnosing papillomatous tumours in the tracheobronchial tree, the possibility of their being verrucous carcinomas should be borne in mind. We believe that a larger number of verrucous carcinomas would be diagnosed by using DNA image cytometry analysis.

○ @ERSpublications

First description of a veruccous carcinoma of the trachea http://ow.ly/tdQvv

Claus Steppert ${ }^{1}$, Joseph Alhanna ${ }^{1}$, Juergen Schubert ${ }^{2}$, Jens Krugmann ${ }^{2}$ and Michael Vieth ${ }^{2}$

${ }^{1}$ Medical Clinic II, Cardiology, Pulmonology and Internal Intensive Care, Klinikum Bayreuth, Bayreuth, and ${ }^{2}$ Dept of Pathology, Klinikum Bayreuth, Bayreuth, Germany.

Correspondence: C. Steppert, Medical Clinic II, Cardiology, Pulmonology and Internal Intensive Care, Klinikum Bayreuth, Preuschwitzer Straße 101, D-95445, Bayreuth, Germany. E-mail: mail@steppert.de

Received: July 282013 | Accepted: Dec 262013 | First published online: Feb 202014

Conflict of interest: None declared

\section{References}

Ackerman LV. Verrucous carcinoma of the oral cavity. Surgery 1948; 23: 670-678.

Koch BB, Trask DK, Hoffman HT, et al. National survey of head and neck verrucous carcinoma: patterns of presentation, care, and outcome. Cancer 2001; 92: 110-120.

3 Ferlito A, Recher G. Ackerman's tumor (verrucous carcinoma) of the larynx: a clinicopathologic study of 77 cases. Cancer 1980; 46: 1617-1630.

4 Kawaida M, Fukuda H, Kohno N. Veruccous carcinoma of the larynx presenting as a hairy whitish tumor. Diagn Ther Endosc 1997; 3: 249-254.

5 Devlin S, Falck V, Urbanski SJ, et al. Verrucous carcinoma of the esophagus eluding multiple sets of endoscopic biopsies and endoscopic ultrasound: a case report and review of the literature. Can J Gastroenterol 2004; 18: 459-462.

6 Brandsma JL, Steinberg BM, Abramson AL, et al. Presence of human papillomavirus type 16 related sequences in veruccous carcinoma of the larynx. Cancer Res 1986; 46: 2185-2188.

7 Schrader M, Laberke HG, Jahnke K. Lymphknotenmetastasen beim verrukosen Karzinom (Ackerman-Tumor) [Lymphatic metastases of verrucous carcinoma (Ackerman tumor)]. HNO 1987; 35: 27-30.

8 Lam CW, Talbot AR, Yeh KT, et al. Human papillomavirus and squamous cell carcinoma in a solitary tracheal papilloma. Ann Thorac Surg 2004; 77: 2201-2202.

9 Miller ME, Martin N, Juillard GF, et al. Temporal bone verrucous carcinoma: outcomes and treatment controversy. Eur Arch Otorhinolaryngol 2010; 267: 1927-1931.

10 Heselmeyer K, Schröck E, du Manoir S, et al. Gain of chromosome 3q denes the transition from severe dysplasia to invasive carcinoma of the uterine cervix. Proc Natl Acad Sci USA 1996; 93: 479-484.

11 Walboomers JM, Jacobs MV, Manos MM, et al. Human papillomavirus is a necessary cause of invasive cervical cancer worldwide. J Pathol 1999; 189: 12-19.

12 Ereño C, Lopez JI, Loizate A, et al. Verrucous carcinoma of the esophagus. Endoscopy 2001; 33: 297.

13 Edström S, Johansson SL, Lindström J, et al. Verrucous squamous cell carcinoma of the larynx: evidence for increased metastatic potential after irradiation. Otolaryngol Head Neck Surg 1987; 97: 381-384. 